\title{
LOOK WHO'S TALKING: ECB COMMUNICATION DURING THE FIRST YEARS OF EMU
}

\author{
DAVID-JAN JANSEN \\ JAKOB DE HAAN
}

\author{
CESIFO WORKING PAPER NO. 1263 \\ CATEgORY 6: MONETARy Policy and InTERnATIONAL Finance \\ August 2004
}




\title{
LOOK WHO'S TALKING: ECB COMMUNICATION DURING THE FIRST YEARS OF EMU
}

\begin{abstract}
This paper studies ECB and Bundesbank communication on monetary policy during the first years of the European Economic and Monetary Union. We study whether statements by different (groups of) central bankers have been contradictory and whether differences have diminished over time. We find that statements on the interest rate, inflation and economic growth have indeed been contradictory. Furthermore, national central banks continue to dominate communication on monetary policy. Finally, only the ECB Executive Board has observed radio silence before ECB Governing Council meetings. A positive conclusion is that, over time, interest rate statements have become less contradictory.
\end{abstract}

JEL Code: E52, E58.

Keywords: central bank communication, European Central Bank, Bundesbank.

David-Jan Jansen

De Nederlandsche Bank

Research Division

P.O.Box 98

1000 AB Amsterdam

The Netherlands

d.jansen@dnb.nl
Jakob de Haan

Department of Economics

University of Groningen

P.O. Box 800

9700 AV Groningen

The Netherlands

j.de.haan@eco.rug.nl 


\section{Introduction}

When the European Central Bank (ECB) started its operations in 1999, financial markets were not yet fully acquainted with the way the ECB would operate. Even though the details of the ECB monetary policy strategy had already been made public, there was considerable uncertainty on how the ECB would implement this strategy. Under these circumstances, clear and coherent ECB communication was of paramount importance. Many observers feel that the ECB has not been very successful in this respect. According to Hämäläinen (2001), who was ECB Executive Board member at the time:

It is true that we have not always been very successful in our communication despite ambitious intentions. But communication is not easy in a pan-European context in which differing cultures, languages, traditions and motives affect how messages are interpreted by the different counter-parties involved.

Meanwhile, the creation of the ECB implied that the roles of national central banks changed. The German Bundesbank, the focal point of European monetary policy for years, became just one of the twelve national central banks within the European System of Central Banks (ESCB). Still, the Bundesbank had a firm track record and the reputation of a tough and successful inflation fighter. Financial market participants in search for information on future monetary policy might, therefore, turn to the old and trusted Bundesbank in order to gather information. In the words of a market participant: 'Bundesbank council members are probably as close as one can get to being a fly on the ECB's wall'1 .

This paper evaluates ECB and Bundesbank communication during the first years of the European Economic and Monetary Union (EMU). We investigate two main issues: i) to what extent have comments by various European central bankers been different or contradictory and ii) how has ECB communication evolved over time. It may be expected that, after some initial problems, ECB communication has improved. So, we would expect possible dispersion in communication on monetary policy to decrease over time. Also, we expect the role of national central banks to decrease.

Firstly, in order to study dispersion in ECB communication, we study whether different (groups of) central bankers have had preferences for different sorts of comments. We make a distinction between members of the ECB Executive Board (EB), national central bank (NCB) presidents and Bundesbank policymakers. We report the topics that were mentioned in their respective statements as well as their contents. In addition, we construct an indicator that measures to what extent ECB comments were contradictory. Finally, we study the distribution of statements by different groups of central bankers surrounding Governing Council (GC) meetings. The ECB may use communication before GC meetings to influence the public's expectations. Alternatively, the ECB may choose to observe radio silence before GC meetings, therewith avoiding confusing financial markets through its statements. We hypothesize that the ECB has chosen the latter course. Therefore, we test whether their have been less statements before GC meetings than after.

\footnotetext{
${ }^{1}$ Source: Bloomberg, 1 August 2001
} 
Our second main research question is related to changes in ECB communication over time. In particular, we investigate whether the agreement of July 1999 between European Ministers of Finance and central bankers to streamline ECB communication on the euro has been successful. Central bankers, save Duisenberg, would make fewer comments, so that financial markets would be less easily confused by ECB communication.

Most research in this field is theoretical in nature (see e.g. Morris and Shin (2002)). This paper uses comments by central bankers as reported by Bloomberg to study central bank communication from an empirical perspective ${ }^{2}$. We have searched the news report archive using keywords like 'ECB' or names of ECB officials. Using this strategy, we have gathered 931 news reports for the period between January 4, 1999 and May 17, 2002. We organize the raw data by classifying it on the basis of the person making the statement and the topic discussed.

Our results are as follows. We conclude that in some respects ECB communication has improved over the years. Firstly, ECB communication on the interest rate has become less contradictory. Also, there is evidence that ECB communication on the euro has been streamlined over the years. In contrast, statements on inflation and growth have become more diffused. In addition, national central banks, in particular the Bundesbank, continue to play an important role in communication on European monetary policy. Finally, only the ECB Executive Board has consistently observed radio silence before rate meetings.

The remainder of this paper is structured as follows. Section 2 discusses the importance of central bank communication. Section 3 describes our methodology. Section 4 gives a first description of the data, whereas section 5 analyses the coherence in ECB communication. Section 6 analyses the distribution of statements surrounding GC meetings, while section 7 examines developments in ECB communication over time. Section 8 summarizes and concludes.

\section{The importance of central bank communication}

\subsection{Theoretical considerations}

We see, at least, three reasons why central banks can benefit from communication. First and foremost, communication may increase the effectiveness of monetary policy. Clear and consistent communication on the long-term inflation target can be used to influence the public's long-run inflation expectations, for example. If this is done successfully, the central bank has more leeway to respond to short-run shocks, as deviations from the inflation target are not interpreted as an indication of a lack of commitment ( King (1997)). Building greater trust by communicating a long-term inflation objective may lead to a lesser degree of inflation persistence, since there is a strong belief that inflation will return to its target level.

Kuttner and Posen (2001) find support for this view. In a study of the response of bond markets (as a proxy for inflation expectations) in Canada, New Zealand, and the UK before and after the central banks in these countries adopted inflation targeting, they

\footnotetext{
${ }^{2}$ Two papers that use a more empirical approach are Siklos and Bohl (2003) and Andersson, Dillén and Sellin (2001). The former focuses on Bundesbank communication before 1998, while the latter analyses communication by the Sveriges Riksbank.
} 
find that interest rates decreased, which is consistent with the view that the adoption of inflation targeting increases flexibility. Kuttner and Posen (1999) report similar results for a broader range of countries: inflation targeting reduces inflation persistence, in contrast to other elements of the monetary framework, like central bank independence. However, Ball and Sheridan (2003), who compare seven OECD countries that adopted inflation targeting in the early 1990s to thirteen countries that did not, do not report supportive evidence. They find that after the early 1990s, performance improved in both the targeting and the non-targeting countries. If targeters improved more than nontargeters, regression to the mean plays an important role: targeters performed worse than non-targeters before the early 1990s. Once regression to the mean is accounted for, there is no evidence that targeting improves performance.

Secondly, communication may be used to reduce noise in markets ( Posen (2003)). Greater disclosure and clarity over policy may lead to greater predictability of central bank actions. This, in turn, reduces the uncertainty in financial markets. The results reported by Kuttner (2001) offer support for this point of view. Changes in the Federal Reserve's disclosure policy have reduced market volatility and increased predictability. Research on the predictability of ECB decisions suggests that most were in line with financial markets' expectations. Gaspar, Pérez Quirós and Sicilia (2001) have analysed whether the announcements of ECB decisions have a significant impact on the behavior of overnight rates (EONIA) in Europe. Their results suggest that markets are able to predict the ECB's interest rate decisions quite accurately over the period of analysis. Somewhat less supportive evidence has been reported by Ross (2002) and De Haan, Eijffinger and Waller (2004), who find that while ECB rate hikes were generally well predicted, the markets have had more difficulty in fully and correctly anticipating ECB rate cuts in terms of either timing or magnitude.

Last, but certainly not least, communication is important from the perspective of accountability. Accountability, in turn, requires disclosure (see e.g. De Haan and Eijffinger (2000)). Even if other arrangements concerning accountability exist, their scope is limited without proper information concerning the behavior of central banks. Communicating via statements is one channel through which information can be transmitted.

Morris and Shin (2002) point out that communication may, in theory, also have detrimental effects. This effect arises from the fact that the impact of public information is large. As a consequence, so is the impact of possible noise in the public signal. Agents may overreact to public information and thereby magnify the damage done by any noise. When public information becomes entrenched it begins to take a life of its own, suppressing the private information of individual agents, and disrupting the channel through which the market mechanism aggregates and disseminates information on economic fundamentals. Morris and Shin (2002) show that such overreaction need not be predicated on any wishful thinking or irrationality on the parts of agents.

\subsection{Perceptions of ECB communication}

Even if a central bank is very active in providing information, the public may, nevertheless, feel that it does not fully understand the central bank's actions. Whether the activities of the central bank lead to a better understanding depends on many factors. One of the crucial factors, of course, is the quality of the information provided. No matter how often a central bank publishes information, if the public feels that this information 
is hard to understand, the central bank is, de facto, not perceived as being transparent.

There are clear indications that financial markets initially did not have a good understanding of the ECB's strategy ${ }^{3}$. According to a survey by Goldman Sachs held in February 2000 in which a sample of financial market participants was asked to rate on a scale of 1 to 5 (a higher grade indicating a better understanding) how well they understood the reasoning behind monetary policy decisions of four central banks, the ECB came out last (see Gros (2000)). Also, in a more recent survey De Haan et al. (2004), professional economists do not rank the ECB as a highly transparent central bank.

The quality of the information is one important factor that explains to what extent the public feels that it understands central bank communication. Another important issue is whether the messages of various officials are the same. If disagreement is present, the public may get confused. On more than one occasion, both Ministers of Finance and central bankers issued statements about the external value of the euro that were at times conflicting. Also, statements by ECB officials were sometimes considered to be conflicting $^{4}$. In order to improve upon this situation, Euro area Finance ministers and central bankers agreed to exercise restraint in their comments about the exchange rate in July 1999. In section 7, we analyze whether policy makers have been successful in this respect.

\subsection{Empirical studies on central bank communication}

Empirical research on central bank communication is scarce. Siklos and Bohl (2003) study Bundesbank communication over the period 1982-1998. Using data on speeches by senior Bundesbank officials, the authors show that speeches are related to changes in the interest rate. More importantly, it matters what the speech is about: communication on prices and economic policy are more important than, for example, speeches on the euro.

Andersson et al. (2001) examine how various monetary policy signals have influenced the term structure of Swedish interest rates. Among these signals, they also rank speeches by Riksbank officials. Their analysis shows that unexpected changes in the repo rate are the most important determinant of movements at the short end of the yield curve. However, at the long end, unexpected signals from speeches turn out to be as important as unexpected repo rate changes. A drawback of their analysis is that over the total sample period (1996-2001), there are only 11 identified speeches.

\footnotetext{
${ }^{3}$ This has led Issing (2001) to conclude that the ECB faces a 'communication gap': 'On the one hand, few observers contest the success and credibility of the ECB in delivering on its primary objective and on the appropriateness of most of its policy actions in this regard... On the other hand, however, the overall perception of the ECB by the public, academics, financial analysts, market participants, and not least, journalists continues to remain - at best - rather mixed'.

${ }^{4}$ An often cited example is when Noyer, at the time the ECB Vice-President, in February 2000 stated that markets had been reading to much in the words of the Monthly Bulletin of that month. Analysts expected an immanent interest rate rise. But on 24 February Noyer reversed this expectation by his remarks. The markets concluded that a rise was unlikely at the next meeting of the Governing Council. In reaction, the euro fell to its lowest level at the time. Indeed, the ECB did not change its rates at 2 March, but it did so two weeks later. Duisenberg explained later that one reason to wait was to avoid appearing to overreact to the euro's weakness. According to Sims and Wessel (2000), it 'still isn't clear whether Mr. Noyer was trying to send a signal, or whether there was disagreement inside the ECB.' Questioned recently about the episode, Noyer says he was giving 'exactly the same message we have tried to convey many times'.
} 


\section{Methodology}

\subsection{Data and sources}

We have collected data on statements by ECB and Bundesbank officials using Bloomberg. We have searched the archive of news reports by scanning the report headlines. In particular, we selected news reports of which the headline contains a reference to the ECB or an ECB Governing Council member. Furthermore, we also selected those statements made by high-level Bundesbank policy makers. We have selected 931 news reports over the period January 4, 1999 to May 17, 2002. For the analysis in section 6, we downloaded the dates of ECB GC meetings from the ECB web-site.

\subsection{Categories of statements}

We classify the statements both by the person making the statement as well as the content of the statement. Concerning persons, we focus on three groups of central bankers (the ECB Executive Board, national central bank presidents, and Bundesbank officials) and several important individuals. The classification for the topics of statements is given in table 1 . There are two main categories ${ }^{5}$ : monetary policy and the euro. There are four subcategories in the monetary policy category. First of all, there are statements on interest rates in the euro area. Secondly, there are statements on money growth in the euro area (the former 'first pillar'), economic growth and inflation (elements of the former 'second pillar').

Table 1: Categories of ECB statements

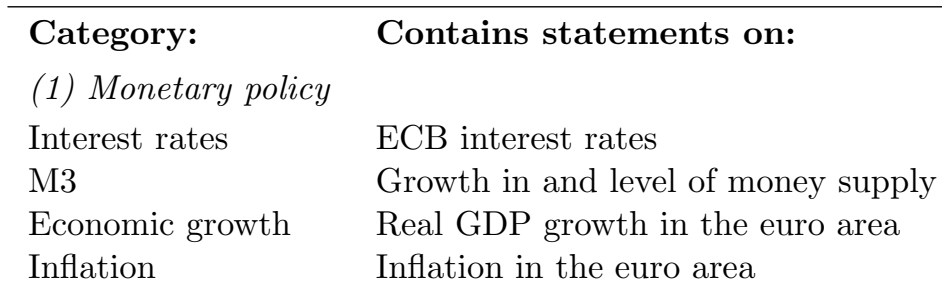

(2) The euro

Future value of euro Expectations on the external value of the euro

Intervention The possibility of intervention

Euro as target? The position of the euro in ECB strategy

The second main category are statements on the euro. During the sample period, developments in the euro-dollar exchange rate were widely discussed. The ECB paid a lot of attention to the euro-dollar exchange rate in its communication for, at least, three reasons. Firstly, politicians and central bankers had promised, more or less, that the euro would be a strong currency. The continued external weakness of the euro was often considered to be in contrast with this claim. Therefore, ECB officials had to reassure the public that the decline of the euro was unjustified and temporary. Secondly, there has been quite some confusion about the role of the exchange rate in the monetary policy strategy of the ECB. Sometimes it was thought that the ECB had an exchange rate

\footnotetext{
${ }^{5}$ We mainly use the same categories as in Jansen and De Haan (2003)
} 
objective, which it did not. However, the ECB closely watched the external value of the euro under what is now called the economic analysis (the previous 'second pillar'), because exchange rate shocks may lead to inflation in the euro area. A final reason why the ECB, no doubt, closely follows exchange rates is that there is always a risk that actual exchange rates may be out of line with economic fundamentals. Indeed, the concerted intervention of the ECB and other central banks at the end of 2000, was, according to an ECB press release, motivated by the 'shared concern about the potential implications of recent movements in the euro exchange rate for the world economy.' Apart from official intervention, the ECB may try to affect the external value of the euro by communicating its worries.

The first subcategory under the second main heading contains statements expressing beliefs on the future direction of the exchange rate. The second subcategory contains statements pertaining to the possibility of future ECB foreign exchange market interventions. Finally, there are statements explaining the position of the euro in the ECB monetary policy strategy.

\section{A first look at statements by central bankers}

\subsection{The ECB Executive Board}

Table 2 shows classifications for the statements made by members of the ECB Executive Board (EB). Columns 2 until 5 show the number of statements on monetary policy, whereas column 6 until 8 show statements on the euro-dollar exchange rate. The final column shows the total number of news reports in which statements were mentioned. In total, the EB has appeared in 360 of such reports.

From table 2, we can conclude that, in comparison with variables from the second pillar of the ECB monetary policy strategy, M3 is hardly mentioned. Growth and inflation are, without doubt, considered very important by the EB, whereas they are a little more cautious about discussing the interest rate. The ranking in terms of the number of statements in the monetary policy category is in line with expectations: Duisenberg has the most number of observations, closely followed by Issing.

It can be seen that Duisenberg, Noyer and Issing were quite concerned about the external value of the euro. Not only did they often discuss the future development of the euro-dollar rate, but they also explained that the euro's external value was not a target for monetary policy. On the possibility of an intervention, only Duisenberg and Noyer have made a significant number of statements.

\subsection{National central bank presidents}

Table 3 shows the total number of statements of NCB presidents ${ }^{6}$. Similar patterns emerge as in the case of the EB. There is relatively little attention for M3 growth; policy makers are more prone to talk about growth and inflation than on interest rates.

There are a few interesting differences, nevertheless. The EB members made a similar number of statements on growth and inflation, whereas the NCB presidents made more statements on inflation than on economic growth. The source for this difference is even

\footnotetext{
${ }^{6}$ For Germany, Spain and Portugal, the presidency switched during the sample period. Therefore, these countries have two presidents listed.
} 


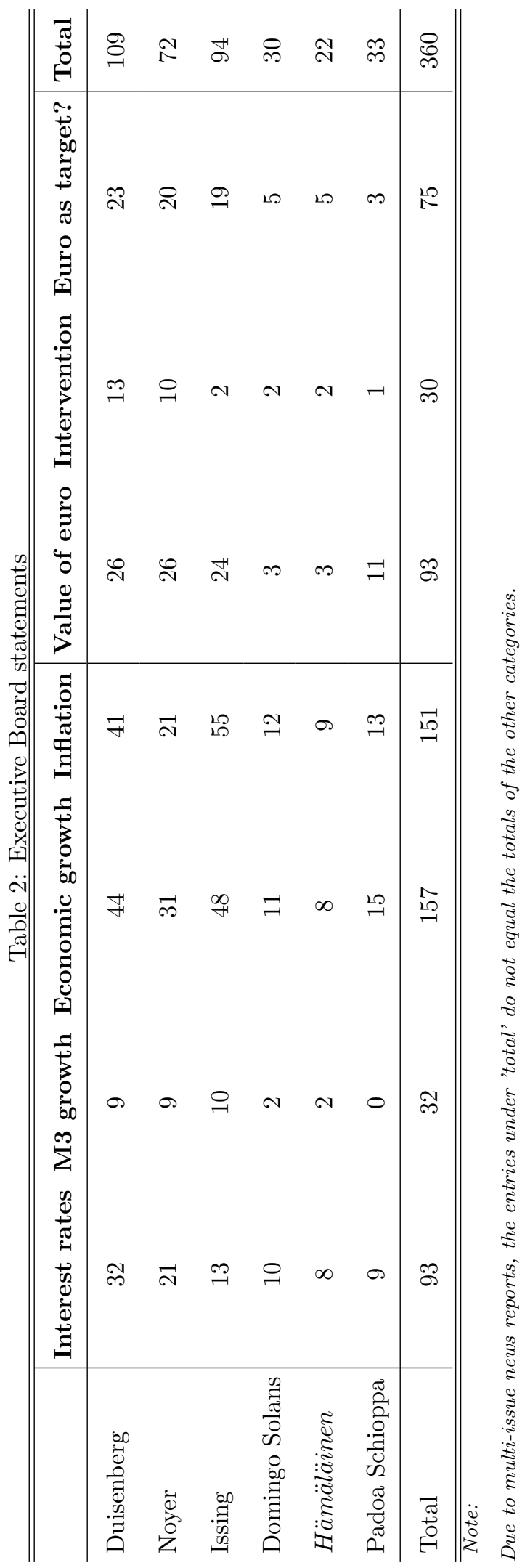


more interesting: a quick comparison shows that it is Bundesbank president Welteke who accounts for the difference. In addition, he accounts for more than $60 \%$ of the statements on M3 growth. Put differently, in his statements Welteke appears to stick to the German monetary tradition with its attention for M3 and a clear emphasis on inflation. The other NCB presidents seem to share his interest in inflation: in most cases they are more often cited on inflation than on growth. Interestingly, the southern central bank presidents hardly mention M3 growth. Only Papademos, currently Vice President of the ECB, is cited on this topic.

Overall, Welteke has made the most statements on monetary policy. Not only has he spoken more on this issue than other national central bank presidents, he also is cited more often than any of the members of the ECB Executive Board. So, in this sense the Bundesbank has kept its pivotal role in European monetary policy. Trichet, the current ECB president, is also quite outspoken. He is cited, approximately, as often as Duisenberg on growth and inflation. Interestingly, Trichet seems to have been relatively silent on interest rate changes. He is cited about 40 times on the first two issues, but only 11 times on interest rates. The Belgian and Austrian central bank presidents have also been in the news quite often. Quaden is cited relatively often on interest rates (16 times), whereas Liebscher is cited more on economic growth and inflation (24 and 25 times, respectively).

Let us now turn our attention to the opinions of NCB presidents on the euro's external value. We find 52 statements on the future value of the euro against the dollar, 20 statements on interventions and 52 statements on the position of the euro in ECB monetary policy. Once again, we find that Welteke is cited most often. During the short part of our sample period when Tietmeyer was Bundesbank president, he has made 14 statements on the euro's value and 9 on the euro as a possible target. So, it seems that he was rather concerned with the euro's external value. Unlike Welteke, Trichet has made only few comments on interventions. The number of comments on the euro's value and the euro as a target are similar for these two central bankers.

\subsection{Bundesbank officials}

As noted, the statements by Bundesbank policy makers warrant some further attention. We have statements from members of the executive board (Direktorium), as well as presidents of the regional central banks (Landeszentralbanken) ${ }^{7}$. Table 4 shows that the presidents of the Landeszentralbanken have made more statements than the members of the Direktorium (except for the Bundesbank president). The number of statements is roughly balanced over the different categories, although there seems to be a slight preference for comments on the interest rate. Especially Meister and Kuehbacher talked relatively often about the interest rate.

One final point is the number of statements on M3 growth. In total, the Bundesbank officials are cited on 17 occasions on this topic. To put this into perspective, the ECB Executive Board was cited only 32 times on this topic. Furthermore, the NCB presidents were cited 17 times if we exclude the observations on Tietmeyer and Welteke. This

\footnotetext{
${ }^{7}$ Just before the end of our sample period, three presidents of regional central banks became member of the executive board (Kotz, Reckers and Zeitler). However, since their statements were made before this transition, they are only listed in the second category.
} 


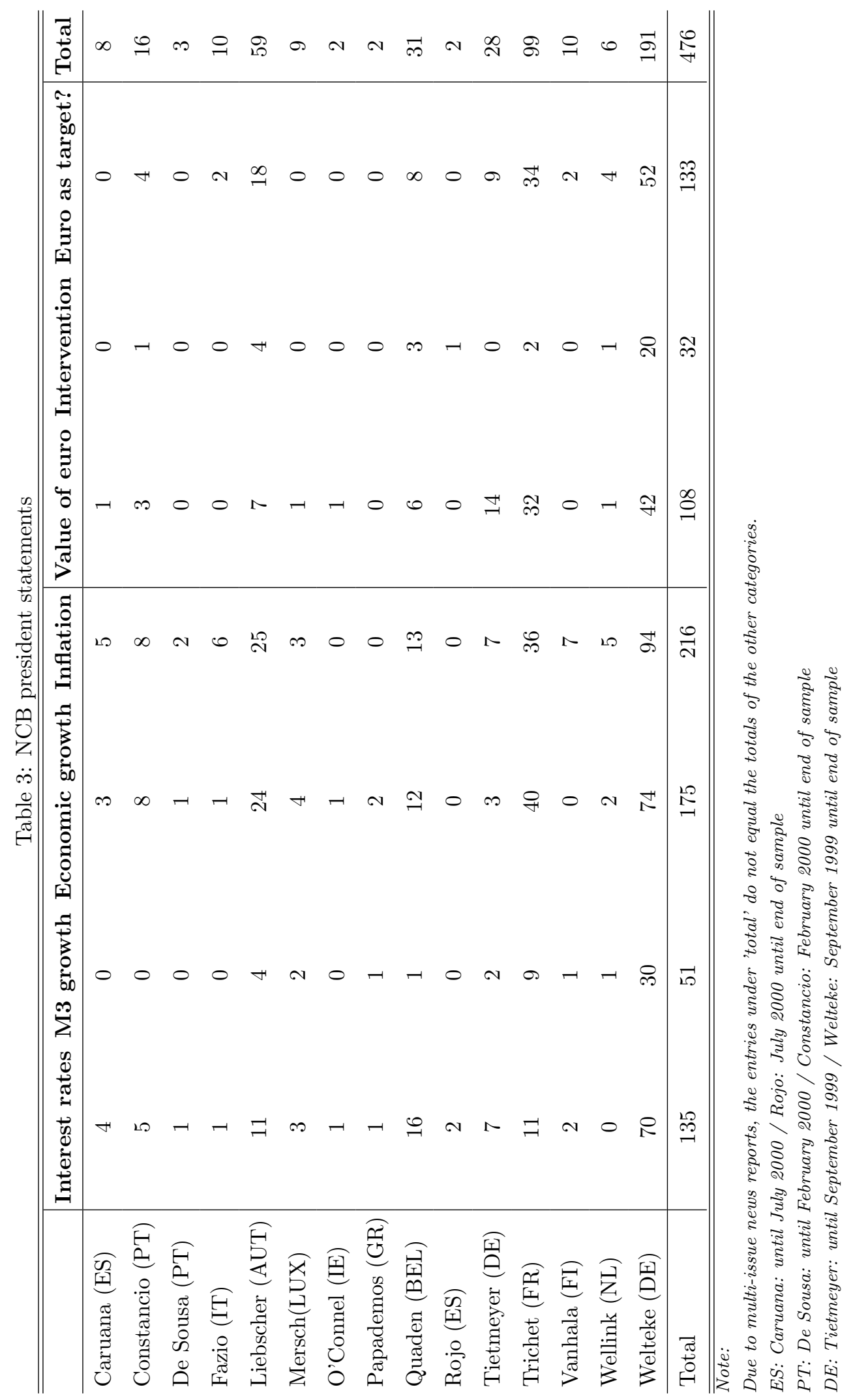




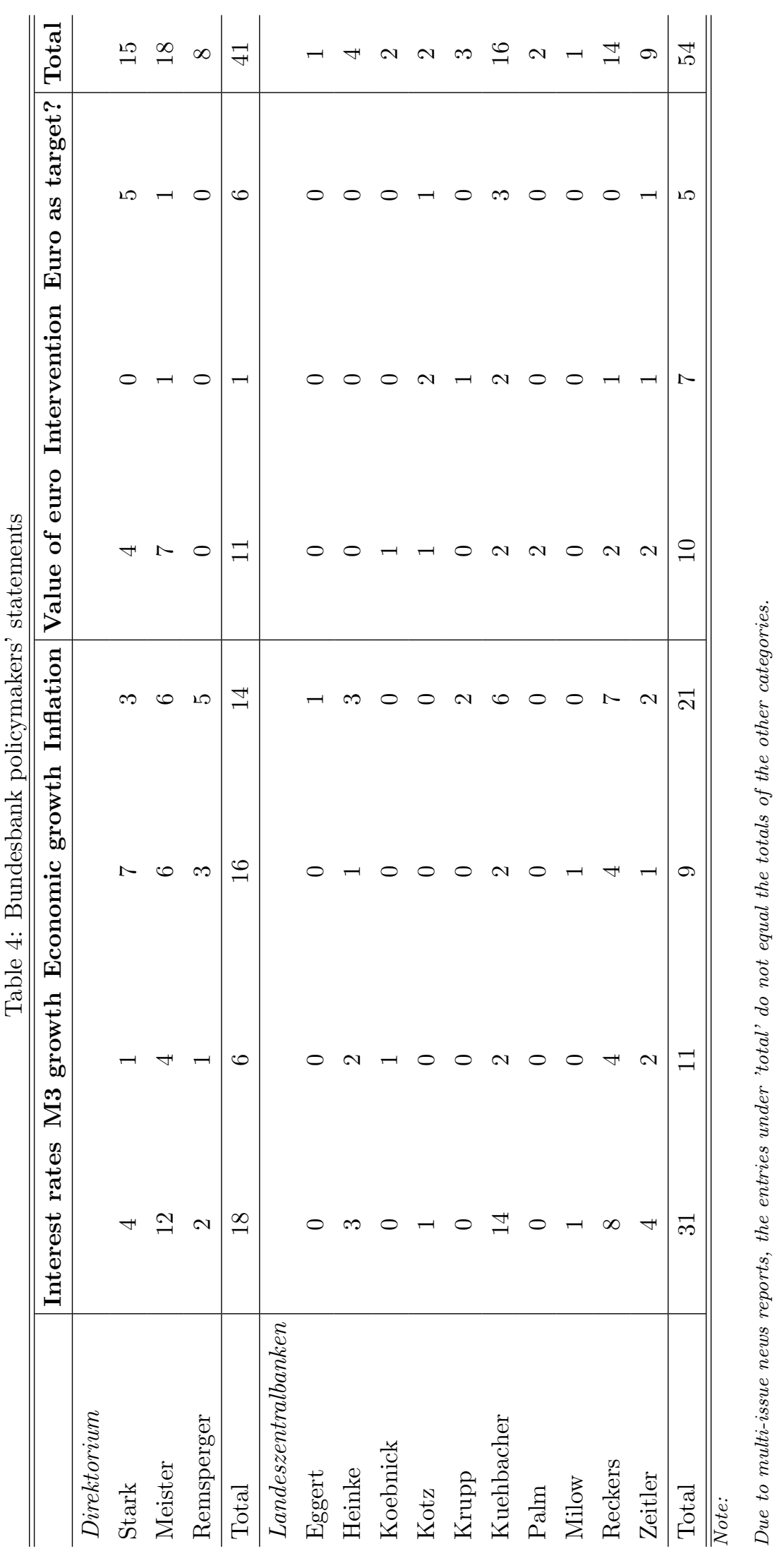


indicates a relative preference of the Bundesbank for a monetary approach to monetary policy, whereas ECB communication is more balanced.

Statements by Bundesbank officials on the euro were made by the Direktorium as well as Landeszentralbank presidents. We find that the number of statements is rather evenly divided between the two groups when the future value of the euro or the position of the euro in monetary policy are concerned. When it comes to intervention, in contrast, the Direktorium made only one statements, whereas the presidents of the Landeszentralbanken made seven. 


\section{Coherence in ECB communication}

\subsection{Dispersion at the group level}

Have ECB statements differed in content? For example, have some central bankers been more positive than others? We will first analyse this issue at the group level, before focusing on some interesting results for individuals.

Table 5 shows the results for four different groups: the ECB Executive Board, NCB presidents, Bundesbank officials (exluding the president) and all statements in the sample. The entries in the table should be read as the percentage of the total number of statements in a particular category. For example, the top-left entry (12.9\%), indicates that of all ECB Executive Board statements on the interest rate, $12.9 \%$ suggesting a rise of the interest rate.

Table 5: Dispersion at the group level

\begin{tabular}{|c|c|c|c|c|c|}
\hline & & ECB EB & NCB Presidents & BuBa a) & All ECB officials \\
\hline \multirow[t]{3}{*}{ Rates } & $\mathrm{Up}$ & 12.9 & 14.1 & 18.4 & 14.4 \\
\hline & 0 & 83.9 & 82.2 & 71.4 & 80.9 \\
\hline & Down & 3.2 & 3.7 & 10.2 & 4.7 \\
\hline \multirow[t]{3}{*}{ M3 growth } & $\mathrm{Up}$ & 31.3 & 24.0 & 41.2 & 29.3 \\
\hline & 0 & 37.5 & 42.0 & 29.4 & 38.4 \\
\hline & Down & 31.3 & 34.0 & 29.4 & 32.3 \\
\hline \multirow[t]{3}{*}{ Growth } & $\mathrm{Up}$ & 82.8 & 72.2 & 52.0 & 75.2 \\
\hline & 0 & 7.0 & 12.5 & 16.0 & 10.3 \\
\hline & Down & 10.2 & 15.3 & 32.0 & 14.5 \\
\hline \multirow[t]{3}{*}{ Inflation } & $\mathrm{Up}$ & 23.8 & 24.9 & 28.6 & 24.6 \\
\hline & 0 & 47.7 & 39.0 & 45.7 & 43.0 \\
\hline & Down & 28.5 & 36.2 & 25.7 & 32.3 \\
\hline \multirow[t]{3}{*}{ Euro } & Rise & 95.7 & 97.2 & 85.7 & 95.5 \\
\hline & 0 & 4.3 & 2.8 & 0.0 & 3.1 \\
\hline & Fall & 0.0 & 0.0 & 14.3 & 1.3 \\
\hline \multirow[t]{3}{*}{ Intervention } & Pos & 23.3 & 37.5 & 25.0 & 29.6 \\
\hline & 0 & 46.7 & 40.6 & 25.0 & 42.3 \\
\hline & Neg & 30.0 & 21.9 & 50.0 & 28.2 \\
\hline \multirow[t]{3}{*}{ Euro as target? } & Pos & 52.0 & 67.9 & 58.3 & 61.7 \\
\hline & 0 & 14.7 & 11.2 & 16.7 & 12.6 \\
\hline & Neg & 33.3 & 20.9 & 25.0 & 25.7 \\
\hline
\end{tabular}

Note:

a) excluding the President

The entries in this table should be read as percentages of the total number of statements per category. The relative small number of observations in some categories may increase the influence of outliers on the reported results.

Starting with statements on the interest rate, we find that the distribution for the ECB Executive Board and the NCB presidents is surprisingly similar. Indications of rising rates are about 13 to $14 \%$ of the total number of observations. In by far the majority of cases (around $82-84 \%$ ) the statement is neutral in character. Bundesbank 
policy makers make fewer neutral statements and both more statements on higher and lower rates. So, the Bundesbank has been more outspoken than the ECB.

Table 5 shows that the EB statements on M3 growth have been reasonably balanced. The distribution of the statements is approximately uniform. In contrast, NCB presidents have less often hinted at a rise in M3 growth, whereas Bundesbank policy makers have pointed to rises in money supply in $40 \%$ of the cases. When it comes to economic growth, the EB and the NCB presidents are both optimistic in the majority of cases. For the Bundesbank, we see markedly more negative statements on growth. We see a similar pattern in the statements on inflation. In this case, the Bundesbank is more inclined to point to higher inflation than the other two groups. Finally, it is interesting to note that the ECB EB is the least outspoken on the subject of inflation. In almost half of the cases they make neutral statements on this subject. The NCB presidents are a little more inclined to indicate a lower inflation rate.

What do we find for the statements in the second main category: the euro? Firstly, for all three groups almost all statements are discuss the potential of the euro to appreciate against the dollar. Of course, this was to be expected: the prolonged fall of the euro against the dollar prompted the ECB to intervene verbally, as discussed in Jansen and De Haan (2003). The exception, once again, are the Bundesbank officials. When talking about intervention, the ECB EB generally indicated that interventions were not likely or remained neutral. The NCB presidents have been slightly more inclined to hint at future interventions. Interestingly, the Bundesbank seems to have been quite opposed to interventions. Finally, all three groups of central bankers have stressed the importance of the external value of the euro with respect to inflation.

\subsection{Dispersion: results for individuals}

We now focus on the statements of some of the leading figures in European monetary policy: Duisenberg, Noyer, Issing, Welteke and Trichet. Concerning the interest rates, we find rather similar patterns: in most cases the statement is neutral $(>85 \%)$ and in some cases it indicated higher interest rates $(10-15 \%)$. Noyer and Welteke are the only ones who have explicitly hinted at lower rates.

Do country-specific characteristics for certain types of statements exist? When looking at the category 'growth', one would almost be tempted to answer this question in the affirmative. Consider Noyer and Trichet: in both cases almost all statements on growth are positive in nature $(92.5-93.5 \%)$. Duisenberg is also quite upbeat on economic growth, although to a lesser extent than Noyer and Trichet. Finally, Issing and Welteke have also been positive in the majority of cases, but in approximately a fifth of the cases they made negative statements on future economic growth.

On inflation, Trichet turns out to be the most balanced with an almost uniform distribution of statements. The other 4 persons have predominantly made neutral statements (40 $-50 \%$ of the cases). Of all persons, Issing was the most likely to hint at higher inflation rates, whereas Noyer pointed mostly at falling inflation rates.

On the euro, there is little disagreement. Everyone has unrelentingly been stressing that the euro will rise in the near future. For statements on intervention we find more variation. Trichet has been the most consistent, as he has only made neutral statements on intervention. Duisenberg and Issing have ruled out future intervention the most, whereas Welteke and Noyer seem to have been the biggest advocates of intervention. 
Finally, let us look at the euro as a possible target for the ECB. It turns out that in their statements Trichet and Noyer have emphasized the euro as a target. Actually, the evidence is quite overwhelming: Noyer has done this in $87 \%$ of the cases and Trichet in $94 \%$. For Welteke and Issing we find similar results, although less marked. For Duisenberg the balance tilts towards negative statements. In over $50 \%$ of the cases, he has emphasized that the euro is not an explicit target.

Table 6: Dispersion: results for selected individuals

\begin{tabular}{l|l|c|c|c|c|c}
\hline \hline & & Duisenberg & Noyer & Issing & Welteke & Trichet \\
\hline Rates & $\mathrm{Up}$ & 15.6 & 14.3 & 15.4 & 10.0 & 9.1 \\
& 0 & 84.4 & 76.2 & 84.6 & 87.1 & 90.9 \\
M3 growth & Down & 0.0 & 9.5 & 0.0 & 2.9 & 0.0 \\
& $\mathrm{Up}$ & 22.2 & 22.2 & 50.0 & 23.3 & 22.2 \\
& 0 & 33.3 & 44.4 & 30.0 & 33.3 & 33.3 \\
Growth & Down & 44.4 & 33.3 & 20.0 & 43.3 & 44.4 \\
& $\mathrm{Up}$ & 84.1 & 93.5 & 72.9 & 66.2 & 92.5 \\
\multirow{5}{*}{ Inflation } & 0 & 9.1 & 0.0 & 8.3 & 13.5 & 5.0 \\
& Down & 6.8 & 6.5 & 18.8 & 20.3 & 2.5 \\
& $\mathrm{Up}$ & 17.1 & 14.3 & 34.5 & 23.4 & 30.6 \\
& 0 & 48.8 & 42.9 & 41.8 & 41.5 & 36.1 \\
& Down & 34.1 & 42.9 & 23.6 & 35.1 & 33.3 \\
\hline \multirow{5}{*}{ Intervention } & Rise & 100.0 & 96.2 & 100.0 & 97.6 & 96.9 \\
& 0 & 0.0 & 3.8 & 0.0 & 2.4 & 3.1 \\
& Fall & 0.0 & 0.0 & 0.0 & 0.0 & 0.0 \\
& Pos & 15.4 & 30.0 & 0.0 & 40.0 & 0.0 \\
& 0 & 46.2 & 50.0 & 50.0 & 40.0 & 100.0 \\
& Neg & 38.5 & 20.0 & 50.0 & 20.0 & 0.0 \\
& Pos & 17.4 & 87.0 & 47.4 & 67.3 & 94.1 \\
& 0 & 30.4 & 0.0 & 15.8 & 7.7 & 0.0 \\
& Neg & 52.2 & 13.0 & 36.8 & 25.0 & 5.9 \\
\hline \hline
\end{tabular}

Note:

The entries in this table should be read as percentages of the total number of statements per category. Please note that the relative small number of observations in some categories may increase the influence of outliers on the reported results.

\subsection{Measuring the level of contradiction in statements}

The preceding results suggest that, on the whole, ECB communication has been fairly consistent. This conclusion would certainly hold for statements on the interest rate. However, until now we have not studied possible contradictions in comments that were made closely after one another. To analyse this, we examine statements on interest rates, inflation and growth during periods between GC meetings ${ }^{8}$.

To measure the extent of disagreement in ECB statements, we construct an indicator that is bounded between zero (no disagreement) and one (complete disagreement). Firstly, we use a ternary scale to categorise the statements on the interest rate, inflation and growth. A score of -1 means that the variable is said to go down (for example, lower inflation in the Euro area), a zero indicates a neutral statement and a score of 1 indicates

\footnotetext{
${ }^{8}$ This means that, in general, our event window is a two-week period.
} 
a rise in the variable (for example, a higher interest rate). The indicator is constructed as the total distance between the scores divided by the maximum total distance between the scores ${ }^{9}$. For example, in case of three statements, the maximum distance equals 4 . If one central banker states that the interest goes up, while the other two suggest that they will remain the same, the scores are: 1,0 and 0 . The total distance between the statements equals 2 and the indicator equals 0.5 .

Figures 1 and 2 show the development of the indicators based on statements for interest rates and inflation ${ }^{10}$ over the years 1999 until mid-2002. Three conclusions stand out. Firstly, considerable disagreement between ECB statements has indeed existed. This is especially true for statements on inflation. Secondly, over time, the inconsistency in communication on the interest rate has diminished. One might argue that fewer statements on this subject have been made, thus reducing potential disagreement. Quite the opposite is true, as the number of statements on interest rates has in fact increased over the time period under consideration. Finally, the indicator for inflation shows that disagreement has actually increased over the years.

Summarizing, it seems that the ECB communication has improved only partly. On the most important policy instrument, there is more clarity. However, on the two most important policy goals, there is more diffusion ${ }^{11}$.

Figure 1: Degree of contradiction in ECB Interest rates statements

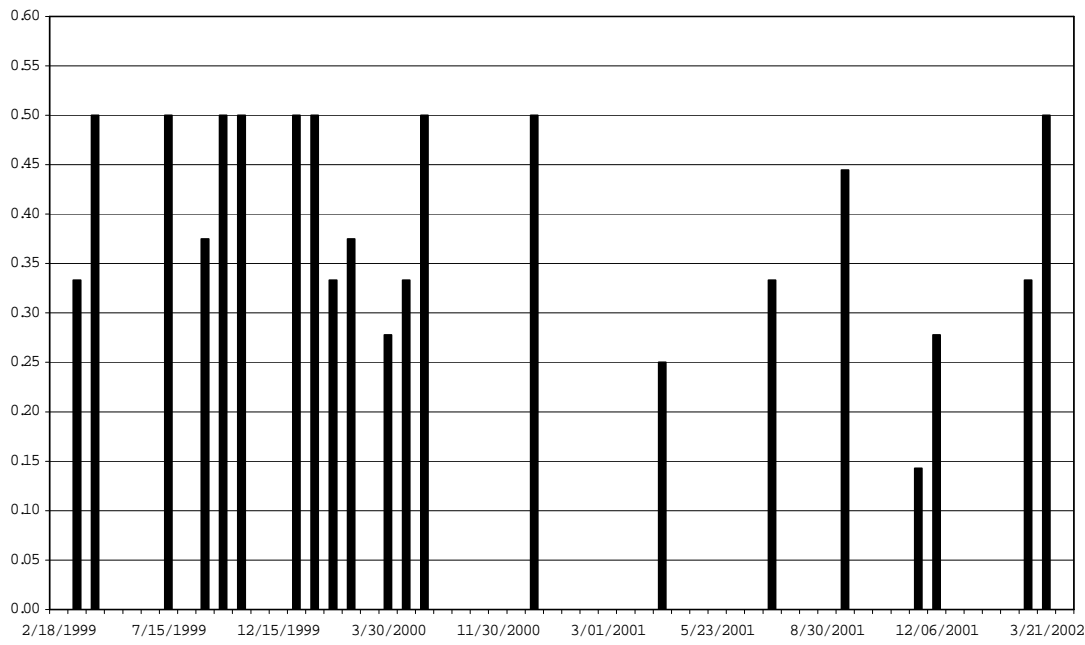

\footnotetext{
${ }^{9}$ The maximum distance is calculated as $0.5 n^{2}$ if $\mathrm{n}$ is an even number and $0.5\left(\left(n^{2}\right)-1\right)$ if $\mathrm{n}$ is an odd number, where $\mathrm{n}$ denotes the number of statements.

${ }^{10}$ Results for statements on inflation and growth (not shown) are similar.

${ }^{11}$ One might argue that the results are influenced by our inclusion of ECB and Bundesbank statements. However, the analysis gives similar results when the Bundesbank comments are excluded. Results are available upon request.
} 
Figure 2: Degree of contradiction in ECB inflation statements

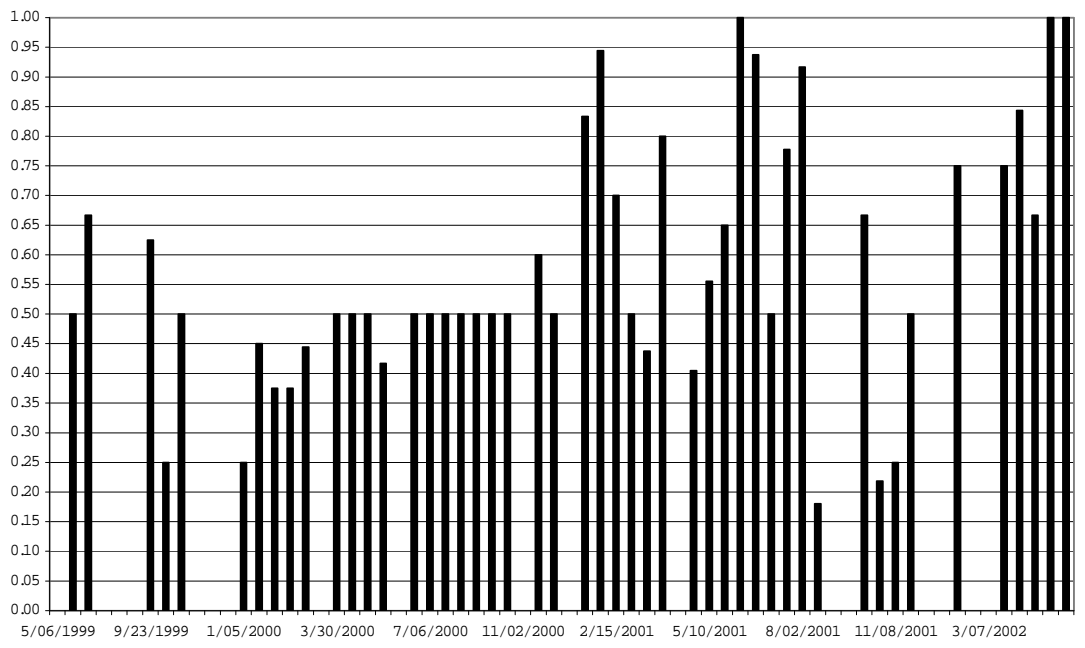

\section{Statements surrounding GC meetings}

\subsection{Did the ECB observe radio silence before GC meetings?}

On a bi-weekly basis, the ECB GC meets to discuss monetary policy. The number and nature of statements surrounding rate decisions may be of prime importance for the effectiveness of monetary policy. In general, a central bank may choose to prepare markets for the upcoming decisions by giving certain hints in its statements. Alternatively, before rate meetings there may be relatively few statements in order to prevent turbulence in financial markets. In this latter case, the distribution of statements around rate meetings will be skewed towards more statements after rate meetings than before.

Figure 3 displays the number of statements on interest rates per day for the Executive Board, NCB presidents and Bundesbank officials ${ }^{12}$. The pattern over time can approximately be characterized as a sinusoid. For the EB, there is a peak on the Fridays preceding GC meetings with a total of nine statements. Subsequently, there is a relative calm over the weekend with 3 statements on Saturdays and 4 on Sundays, before a rise on the Monday to 11 statements. Thus, there evidence suggests that the EB restricts communication in order to prevent turbulence in financial markets.

In this respect, there is a stark contrast with the other two groups of central bankers. On Tuesdays and Wednesdays before GC meetings there were 12 and 10 statements by NCB presidents and 7 and 8 statement by Bundesbank officials, respectively. So, radio silence was not strictly observed by these parties.

After the ECB has announced its policy decision on the interest rate, statements are important for two purposes: explaining and, once again, predicting future policy. On the three days after the GC meeting, the $\mathrm{EB}$ dominates the news reports. In the week after the GC meeting, the NCB presidents make the most number of statements by far (14 on Mondays and 18 on Tuesdays). The Bundesbank officials keep a low profile during these

\footnotetext{
${ }^{12}$ Note that, due to possible overlapping observations, we can only use the six days before and after a rate meeting. Therefore, the total number of statements in figure 1 does not correspond with the figures in tables 2,4 and 6 .
} 
days.

Figure 3: Number of ECB statements surrounding GC meetings

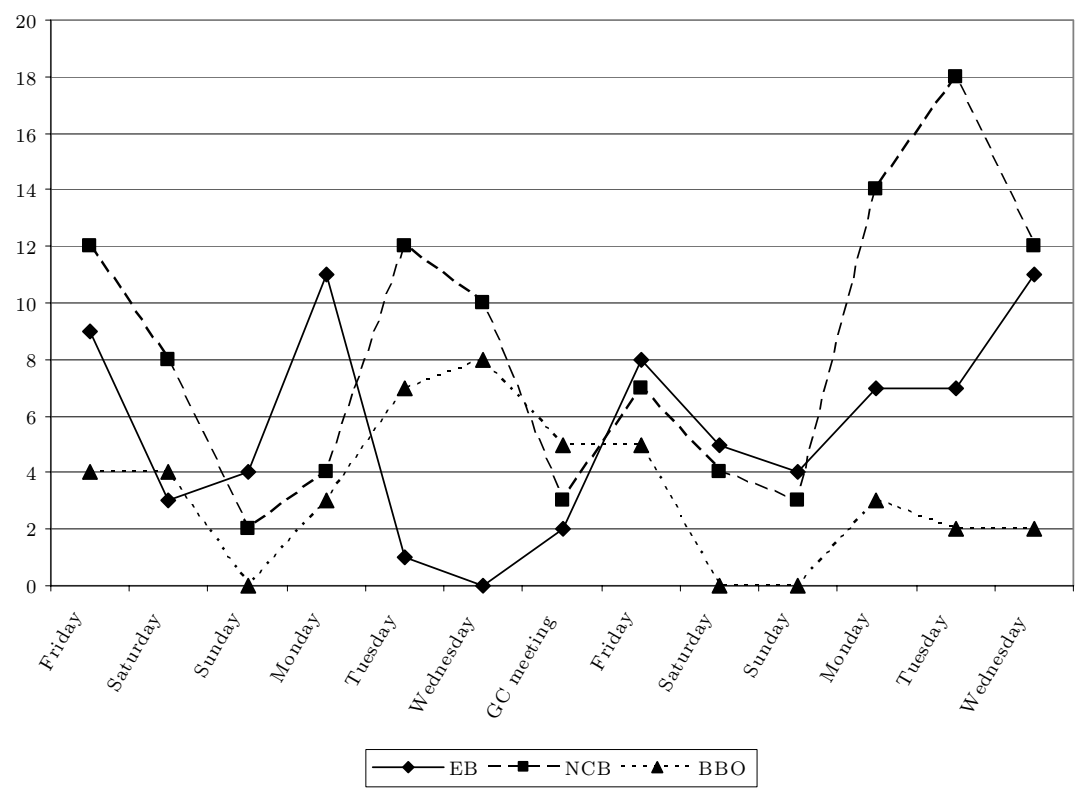

\subsection{Radio silence: results}

To test formally for differences in communication after and before rate meetings, we use the Wilcoxon signed-rank test for matched-pairs ${ }^{13}$. Define $x_{i}^{b}$ as the number of statements on the i'th days before a Governing Council meeting and $x_{i}^{a}$ as the number of statements on the i'th day after a GC meeting. We perform a one-sided test of the null hypothesis that the distributions of $x_{i}^{a}$ and $x_{i}^{b}$ are equal against the one-sided alternative that the distribution of $x_{i}^{a}$ is displaced over that of $x_{i}^{b}$ for $i=1 \ldots 6$. The test results for different categories of statements are displayed in table 7 . The third column presents the average difference between the pairs $x^{a}$ and $x^{b}$. The fourth column presents the Wilcoxon T+-statistic.

Regarding the EB, $\overline{x_{i}^{a}}-\overline{x_{i}^{b}}$ is positive for all cases except intervention. For growth, inflation and the euro, the difference is statistically significant. In a way, this is surprising. One could imagine the ECB to have been fairly careful with statements on the interest rate. In addition, statements on growth and inflation may have been used to prepare the markets for upcoming decisions to some extent. Our results suggest that the opposite has occurred. Finally, for the NCB presidents, the only significant result emerges for M3, while for the Bundesbank officials, we find no significant results.

\footnotetext{
${ }^{13}$ See Marascuilo and McSweeney (1977) for a description of this test and a tabulation of critical values for the T+-statistic.
} 
Table 7: Testing for radio silence: Wilcoxon signed-rank tests

\begin{tabular}{l|l|l|l}
\hline \hline Group & Topic & $\overline{x_{i}^{a}-x_{i}^{b}}$ & Wilcoxon T+ \\
\hline Executive Board & Rates & 2.3 & 16 \\
& M3 growth & 1.5 & 16.5 \\
& Growth & 8.3 & $20^{* *}$ \\
& Inflation & 6 & $19.5^{* *}$ \\
& Euro & 5.7 & $20^{* *}$ \\
& Intervention & -0.2 & 8 \\
& Target & 3 & 15 \\
\hline National central bank presidents & Rates & 1.7 & 11 \\
& M3 growth & 3.3 & $19.5^{* *}$ \\
& Growth & 2.7 & 14.5 \\
& Inflation & 3.3 & 16 \\
& Euro & 1.5 & 13 \\
& Intervention & -1 & 4 \\
& Target & 0.8 & 12 \\
\hline Bundesbank & Rates & -2.3 & 4 \\
& M3 growth & -0.8 & 6 \\
& Growth & -1 & 4.5 \\
& Inflation & -1.7 & 4.5 \\
& Euro & 0.7 & 14 \\
& Intervention & 0.3 & 13 \\
& Target & -0.3 & 0 \\
\hline
\end{tabular}

The entries in the third column give the average difference between the respective number of statements on days after and before a GC meeting. The entries in the fourth column are the resulting $T+$ statistics from the Wilcoxon signed rank test. Since we have $n=6$, the critical values for the appropriate one-sided test are 18 (10\%), 19 (5\%) and 21 (2.5\%) respectively. */**/*** denote significance at the 10/5/2.5\% level 


\section{Did the emphasis in communication change over time?}

\subsection{Distribution of statements over time}

How did ECB communication evolve over time? Did officials talk more about a certain topic during particular periods? Is there evidence that the agreement of July 1999 to streamline communication has been successful? We answer these questions by computing the average number of statements per day for each half year in the sample period. Table 8 reports the results. Standard errors are reported in parentheses.

A quick inspection of table 8 suffices to conclude that there is no clear reduction in the average number of statements over the sample period, as far as the four monetary policy categories are concerned. In contrast, in most cases the average number of statements has risen during the sample period.

Consider, for example, the statements by the EB on interest rates. During the first half of 1999, the average number of statements per day was 0.06. During the first part of 2002 , this figure had risen to 0.08. In the meantime, it had been equal to or more than 0.06 in all but one period (2000-II). For both the NCB presidents and the Bundesbank officials, we find that the average number of statements has risen. The same conclusion hold for statements by the EB and the NCB presidents on growth and inflation. During the first half year of 1999, the average number of statements on growth for these groups were 0.06 and 0.02 , respectively. For inflation, we find averages of 0.02 and 0.02 . During the sample period, the averages follow an upward trend to levels between 0.15 and 0.25 in the first half of 2002 .

Interestingly, there is no evidence that the NCB presidents have become less important in ECB communication over time. Compare, for example, statements on the interest rate. During all periods, the average for the NCB presidents is equal to or larger than that of the EB. Except for statements on growth and inflation this conclusion holds for other categories of statements as well.

Turning to statements on the euro, we do find evidence of a reduction the number of statements. The future value of the euro clearly received more attention during the second half of 1999 and 2000 than in later periods. The same conclusion hold for interventions and the euro as a possible target. However, over time these topics receded from public discussion. These observations taken together may be interpreted as evidence in favor of the success of the July 1999 agreement: central bankers made fewer statements on the euro. 
Table 8: Average number of statements per day

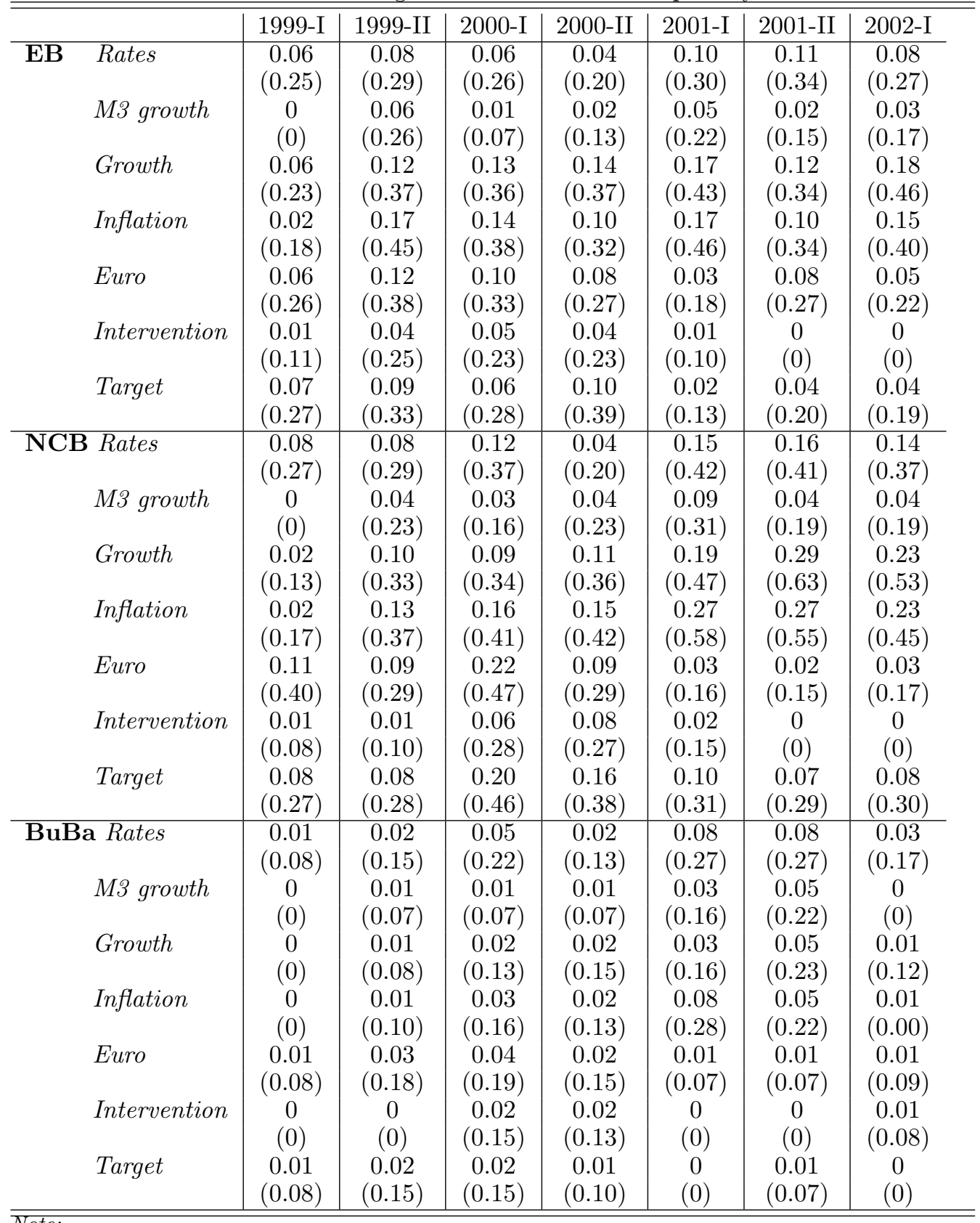

This table displays the average number of statements per day. Results are reported for three groups: Executive Board (EB), national central bank presidents (NCB) and the Bundesbank (BuBa). Standard deviations are reported in brackets. 


\section{Conclusions}

This paper has examined communication by European central bankers during the first years of EMU. We have studied to what extent statements on monetary policy in the Euro area have been contradictory. We find evidence of considerable noise in communication on European monetary policy.

Firstly, we provide evidence that the Bundesbank and national central bank presidents have made as least as many statements as members of the ECB Executive Board. There is no evidence that this trend has been reversed over the years. A situation in which information can emanate from many different sources is more likely to lead to confusing messages. Indeed, we find clear evidence that statements on interest rates, inflation and growth have been contradictory. On the bright side, confusion in interest statements has diminished over the years. Also, there are less instances of confusing statements. However, when inflation and growth are concerned, disagreement has clearly increased over the years.

Finally, we provide evidence that different groups of central bankers have followed different communication strategies surrounding ECB Governing Council meetings. The ECB Executive Board is the only group that has tried to observe radio silence before GC meetings. Both for national central bank presidents and Bundesbank officials, we find no evidence that they communicate less before rather than after GC meetings.

\section{Acknowledgements}

Maarten Bosker provided us with helpful Gauss codes. Het Financieele Dagblad kindly enabled us to use their Bloomberg terminal. Comments by Philipp Maier, Bob Chirinko and members of the DNB research group on 'Information, uncertainty and monetary policy' are gratefully acknowledged. The views expressed in this paper do not necessarily coincide with those of De Nederlandsche Bank. 


\section{References}

Andersson, M., H. Dillén and P. Sellin (2001), 'Monetary policy signaling and movements in the Swedish term structure of interest rates', Sveriges Riksbank Working Paper Series 132.

Ball, L. and N. Sheridan (2003), 'Does inflation targeting matter?', NBER Working Paper 9577.

De Haan, J. and S.C.W. Eijffinger (2000), 'The democratic accountability of the European Central Bank: A comment on two fairy-tales', Journal of Common Market Studies 38(3), 393-407.

De Haan, J., S.C.W. Eijffinger and S. Waller (2004), The ECB: Centralization, transparency and credibility, Cambridge (MA): MIT Press, forthcoming.

Gaspar, V., G. Pérez Quirós and J. Sicilia (2001), 'The ECB monetary policy strategy and the money market', ECB Working Paper 69.

Gros, D. (2000), Quo Vadis Euro? The cost of muddling through, Brussels: CEPS.

Hämäläinen, S. (2001), The ECB's monetary policy; Accountability, Transparency and Communication, in 'Old Age, New Economy and Central Banking Conference', CEPR/ESI and Suomen Pankki.

Issing, O. (2001), 'The Euro Area and the single monetary policy', Oesterreichische Nationalbank Working Paper 44.

Jansen, D. and J. De Haan (2003), 'Statements of ECB officials and their effects on the level and volatility of the euro-dollar exchange rate', CESifo Working Paper Series 927.

King, M. (1997), 'Changes in UK monetary policy: Rules and discretion in practice', Journal of Monetary Economics 39, 81-97.

Kuttner, K.N. (2001), 'Monetary policy surprises and interest rates: Evidence from the Fed funds futures market', Journal of Monetary Economics 47(3), 523-544.

Kuttner, K.N. and A.S. Posen (1999), 'Does talk matter after all? Inflation targeting and central bank behaviour', Institute for International Economics Working Paper 99-10.

Kuttner, K.N. and A.S. Posen (2001), Inflation, monetary transparency and G3 exchange rate volatility, in M.Balling, E.Hochreiter and E.Hennessy, eds, 'Adapting to financial globalization', London: Routledge.

Marascuilo, L.A. and M. McSweeney (1977), Nonparametric and Distribution-Free Methods for the Social Sciences, Monterey (CA): Brooks/Cole Publishing Company.

Morris, S. and H.S. Shin (2002), 'Social value of public information', American Economic Review 92(5), 1521-1534. 
Posen, A.S. (2003), Six practical views of central bank transparency, in P.Mitzen, ed., 'Central banks, monetary theory and policy: Essays in honour of Charles Goodhart', London: Edward Elgar.

Ross, K. (2002), 'Market predictability of ECB monetary policy decisions: A comparative examination', IMF Working Paper 02/233.

Siklos, P.L. and M.T. Bohl (2003), 'Do words speak louder than actions? The conduct of monetary policy at the Bundesbank', mimeo .

Sims, G.T. and D. Wessel (2000), 'The European Central Bank can't master communication', The Wall Street Journal 27 April. 


\section{CESifo Working Paper Series}

(for full list see www.cesifo.de)

1200 Henk C. Kranendonk, Jan Bonenkamp, and Johan P. Verbruggen, A Leading Indicator for the Dutch Economy - Methodological and Empirical Revision of the CPB System, May 2004

1201 Michael Ehrmann, Firm Size and Monetary Policy Transmission - Evidence from German Business Survey Data, May 2004

1202 Thomas A. Knetsch, Evaluating the German Inventory Cycle - Using Data from the Ifo Business Survey, May 2004

1203 Stefan Mittnik and Peter Zadrozny, Forecasting Quarterly German GDP at Monthly Intervals Using Monthly IFO Business Conditions Data, May 2004

1204 Elmer Sterken, The Role of the IFO Business Climate Indicator and Asset Prices in German Monetary Policy, May 2004

1205 Jan Jacobs and Jan-Egbert Sturm, Do Ifo Indicators Help Explain Revisions in German Industrial Production?, May 2004

1206 Ulrich Woitek, Real Wages and Business Cycle Asymmetries, May 2004

1207 Burkhard Heer and Alfred Maußner, Computation of Business Cycle Models: A Comparison of Numerical Methods, June 2004

1208 Costas Hadjiyiannis, Panos Hatzipanayotou, and Michael S. Michael, Pollution and Capital Tax Competition within a Regional Block, June 2004

1209 Stephan Klasen and Thorsten Nestmann, Population, Population Density, and Technological Change, June 2004

1210 Wolfgang Ochel, Welfare Time Limits in the United States - Experiences with a New Welfare-to-Work Approach, June 2004

1211 Luis H. R. Alvarez and Erkki Koskela, Taxation and Rotation Age under Stochastic Forest Stand Value, June 2004

1212 Bernard M. S. van Praag, The Connexion Between Old and New Approaches to Financial Satisfaction, June 2004

1213 Hendrik Hakenes and Martin Peitz, Selling Reputation When Going out of Business, June 2004

1214 Heikki Oksanen, Public Pensions in the National Accounts and Public Finance Targets, June 2004 
1215 Ernst Fehr, Alexander Klein, and Klaus M. Schmidt, Contracts, Fairness, and Incentives, June 2004

1216 Amihai Glazer, Vesa Kanniainen, and Panu Poutvaara, Initial Luck, Status-Seeking and Snowballs Lead to Corporate Success and Failure, June 2004

1217 Bum J. Kim and Harris Schlesinger, Adverse Selection in an Insurance Market with Government-Guaranteed Subsistence Levels, June 2004

1218 Armin Falk, Charitable Giving as a Gift Exchange - Evidence from a Field Experiment, June 2004

1219 Rainer Niemann, Asymmetric Taxation and Cross-Border Investment Decisions, June 2004

1220 Christian Holzner, Volker Meier, and Martin Werding, Time Limits on Welfare Use under Involuntary Unemployment, June 2004

1221 Michiel Evers, Ruud A. de Mooij, and Herman R. J. Vollebergh, Tax Competition under Minimum Rates: The Case of European Diesel Excises, June 2004

1222 S. Brock Blomberg and Gregory D. Hess, How Much Does Violence Tax Trade?, June 2004

1223 Josse Delfgaauw and Robert Dur, Incentives and Workers' Motivation in the Public Sector, June 2004

1224 Paul De Grauwe and Cláudia Costa Storti, The Effects of Monetary Policy: A MetaAnalysis, June 2004

1225 Volker Grossmann, How to Promote R\&D-based Growth? Public Education Expenditure on Scientists and Engineers versus R\&D Subsidies, June 2004

1226 Bart Cockx and Jean Ries, The Exhaustion of Unemployment Benefits in Belgium. Does it Enhance the Probability of Employment?, June 2004

1227 Bertil Holmlund, Sickness Absence and Search Unemployment, June 2004

1228 Klaas J. Beniers and Robert Dur, Politicians' Motivation, Political Culture, and Electoral Competition, June 2004

1229 M. Hashem Pesaran, General Diagnostic Tests for Cross Section Dependence in Panels, July 2004

1230 Wladimir Raymond, Pierre Mohnen, Franz Palm, and Sybrand Schim van der Loeff, An Empirically-Based Taxonomy of Dutch Manufacturing: Innovation Policy Implications, July 2004

1231 Stefan Homburg, A New Approach to Optimal Commodity Taxation, July 2004 
1232 Lorenzo Cappellari and Stephen P. Jenkins, Modelling Low Pay Transition Probabilities, Accounting for Panel Attrition, Non-Response, and Initial Conditions, July 2004

1233 Cheng Hsiao and M. Hashem Pesaran, Random Coefficient Panel Data Models, July 2004

1234 Frederick van der Ploeg, The Welfare State, Redistribution and the Economy, Reciprocal Altruism, Consumer Rivalry and Second Best, July 2004

1235 Thomas Fuchs and Ludger Woessmann, What Accounts for International Differences in Student Performance? A Re-Examination Using PISA Data, July 2004

1236 Pascalis Raimondos-Møller and Alan D. Woodland, Measuring Tax Efficiency: A Tax Optimality Index, July 2004

1237 M. Hashem Pesaran, Davide Pettenuzzo, and Allan Timmermann, Forecasting Time Series Subject to Multiple Structural Breaks, July 2004

1238 Panu Poutvaara and Andreas Wagener, The Invisible Hand Plays Dice: Eventualities in Religious Markets, July 2004

1239 Eckhard Janeba, Moral Federalism, July 2004

1240 Robert S. Chirinko, Steven M. Fazzari, and Andrew P. Meyer, That Elusive Elasticity: A Long-Panel Approach to Estimating the Capital-Labor Substitution Elasticity, July 2004

1241 Hans Jarle Kind, Karen Helene Midelfart, Guttorm Schjelderup, Corporate Tax Systems, Multinational Enterprises, and Economic Integration, July 2004

1242 Vankatesh Bala and Ngo Van Long, International Trade and Cultural Diversity: A Model of Preference Selection, July 2004

1243 Wolfgang Eggert and Alfons J. Weichenrieder, On the Economics of Bottle Deposits, July 2004

1244 Sören Blomquist and Vidar Christiansen, Taxation and Heterogeneous Preferences, July 2004

1245 Rafael Lalive and Alois Stutzer, Approval of Equal Rights and Gender Differences in Well-Being, July 2004

1246 Paolo M. Panteghini, Wide vs. Narrow Tax Bases under Optimal Investment Timing, July 2004

1247 Marika Karanassou, Hector Sala, and Dennis J. Snower, Unemployment in the European Union: Institutions, Prices, and Growth, July 2004

1248 Engin Dalgic and Ngo Van Long, Corrupt Local Government as Resource Farmers: The Helping Hand and the Grabbing Hand, July 2004 
1249 Francesco Giavazzi and Guido Tabellini, Economic and Political Liberalizations, July 2004

1250 Yin-Wong Cheung and Jude Yuen, An Output Perspective on a Northeast Asia Currency Union, August 2004

1251 Ralf Elsas, Frank Heinemann, and Marcel Tyrell, Multiple but Asymmetric Bank Financing: The Case of Relationship Lending, August 2004

1252 Steinar Holden, Wage Formation under Low Inflation, August 2004

1253 Ngo Van Long and Gerhard Sorger, Insecure Property Rights and Growth: The Roles of Appropriation Costs, Wealth Effects, and Heterogeneity, August 2004

1254 Klaus Wälde and Pia Weiß, International Competition, Slim Firms and Wage Inequality, August 2004

1255 Jeremy S. S. Edwards and Alfons J. Weichenrieder, How Weak is the Weakest-Link Principle? On the Measurement of Firm Owners' Control Rights, August 2004

1256 Guido Tabellini, The Role of the State in Economic Development, August 2004

1257 François Larmande and Jean-Pierre Ponssard, EVA and the Controllability-congruence Trade-off: An Empirical Investigation, August 2004

1258 Vesa Kanniainen and Jenni Pääkkönen, Anonymous Money, Moral Sentiments and Welfare, August 2004

1259 Panu Poutvaara and Andreas Wagener, Why is the Public Sector More Labor-Intensive? A Distortionary Tax Argument, August 2004

1260 Lars P. Feld and Stefan Voigt, Making Judges Independent - Some Proposals Regarding the Judiciary, August 2004

1261 Joop Hartog, Hans van Ophem, and Simona Maria Bajdechi, How Risky is Investment in Human Capital?, August 2004

1262 Thomas Eichner and Rüdiger Pethig, Efficient Nonanthropocentric Nature Protection, August 2004

1263 David-Jan Jansen and Jakob de Haan, Look Who's Talking: ECB Communication during the First Years of EMU, August 2004 